\title{
Changes and disruptions in diagnosis, treatment and follow-up of breast cancer during two periods of the COVID-19 pandemic in Turkey
}

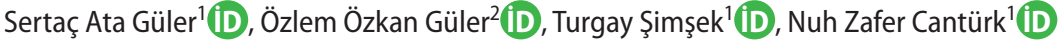 \\ 1 Department of General Surgery, Kocaeli University Faculty of Medicine, Kocaeli, Turkey \\ ${ }^{2}$ Department of Infectious Diseases and Clinical Microbiology, Kocaeli University Faculty of Medicine, Kocaeli, Turkey
}

\begin{abstract}
Objective: COVID-19 disease, which rapidly became a pandemic, led to significant changes in the provision of health services. This included radical changes to the supply and delivery of routine services to release resources for emergency care. During this process, a range of restrictions were imposed including the recommended rules to be followed before, during and after surgery. Health services provided for breast cancer diagnosis, treatment and follow-up have also undergone enforced changes meaning the diagnosis, treatment, and follow-up of patients with priority has come to the fore. In this study, the effect of the COVID-19 pandemic in Turkey, between March 11, 2020 and May 31, 2020 was assessed in comparison to pre-pandemic practice in terms of divided into two periods, and breast cancer diagnosis, treatment, and follow-up.

Material and Methods: Surgeons dealing with breast cancer treatment and registered to SENATURK (Turkish Senology Academy) were contacted online. The period was divided into two, between March $11^{\text {th }}$ and April $30^{\text {th }}$ and May $1^{\text {st }}$ to May $31^{\text {st }}, 2020$. Surgeons were requested to complete two electronic evaluation forms, one for each period, investigating change in practice. Only complete responses for both periods were included in the analysis.

Results: There were 93 respondents. Except for less multidisciplinary breast councils, there was no delay in radiological and pathological diagnoses. The number of breast cancer surgeries increased in Period 2, and more COVID-19 positive breast cancer patients were operated in Period 2. Benign breast patients were delayed less frequently in Period 2 . In the statistical analysis performed between the two groups, it was found that only a significant difference was in the number of outpatients with benign breasts.
\end{abstract}

Conclusion: With sufficient awareness of the risks of COVID-19 and with individual protection, breast cancer treatment was not affected during the assessed period of active pandemic in Turkey.

Keywords: Breast cancer, COVID-19, breast care, breast surgery, disruption

Cite this article as: Güler SA, Özkan Güler Ö, Şimşek T, Cantürk NZ. Changes and disruptions in diagnosis, treatment and follow-up of breast cancer during two periods of the COVID-19 pandemic in Turkey. Turk J Surg 2021; 37 (3): $222-231$

\section{Corresponding Author}

Sertaç Ata Güler

E-mail: drsataguler@me.com

Received: 07.10.2020

Accepted: 12.08 .2021

Available Online Date: 28.09 .202

o Copyright 2021 by Turkish Surgical Society Available online at www.turkjsurg.com

DOI: 10.47717/turkjsurg.2021.5069

\section{INTRODUCTION}

Infection with a novel virion was first seen in the Wuhan region of China in December 2019 and spread rapidly to become a pandemic. The infection appeared to be extremely virulent and infectious and had a high mortality rate, particularly in the elderly and those with comorbid disease. The virus belonged to the Coronavirus family which includes viruses that caused the SARS (2002) and MERS (2012) epidemics, and the new disease was called COVID-19. The virus became known as New Coronavirus 2019 (2019-nCoV) and later as SARS-CoV-2 (1). The pandemic immediately imposed extra demands on global health resources. Radical changes to practice were made to protect both healthcare professionals and patients $(2,3)$. In Turkey, the first case was registered on March 10, 2020, and the first COVID-19 deaths were reported on March 15, 2020.

Since then, there have been major changes in society and in national health services to limit infectious spread and the morbidity and mortality associated with COVID-19. Health service changes have included significant disruption of routine health provision, including surgical services. Recommended rules to be followed before, during and after surgery have been published, both nationally and internationally $(4,5)$. Health services provided for breast cancer diagnosis, treatment and follow-up have also been forced into adapting to the new conditions. There 
has been a greater emphasis on diagnosis, treatment, and follow-up of patients with priority $(3,6)$. For this purpose, some decisions were taken, and recommendations were published $(6,7)$. In Turkey, the fight against COVID-19 was most active until June 1,2020, which was considered the beginning of a normalization process. The initial period, between the first cases appearing and the end of April is considered the "shock" period, while from 1st of May until the beginning of June is considered the period of relative adaptation in terms of the health professionals' and patients' behaviors.

Our aim was to evaluate the changes and disruption to the diagnosis, treatment, and follow-up of breast cancer, divided into the two periods defined, in response to the decisions taken in national health services in response to the COVID-19 pandemic.

\section{MATERIAL and METHODS}

This study was a cross-sectional design over two periods during the COVID-19 pandemic. The study was performed online as a national survey of surgical members of SENATURK (Turkish Senology Academy) treating breast cancer. The first period started from the introduction of restrictions following the detection of the first case on the $11^{\text {th }}$ of March and extended until April $30^{\text {th }}$. This period may be thought of as the "shock" period (Period 1). The second period extended from the $1^{\text {st }}$ of May until the $31^{\text {st }}$ of May and can be thought of as the period of relative adaption (Period 2). An online questionnaire was designed for each period and sent to all members of SENATURK. During these two periods, demographic information of the surgeons dealing with breast cancer, information concerning their institutions and local approach to COVID-19, the status of breast cancer surgery during the period, the changes in surgical approach, and outpatient and diagnostic effects in this period were interrogated. All respondents were asked to answer the questionnaires in comparison to pre-COVID practice. The surveys for both periods, answered by the same surgeons were included to the study. Surgeons who did not complete the surveys and those answering only for one period were excluded.

In accordance with the decisions taken by the Republic of Turkey Ministry of Health for the pandemic period, an application was made to the Scientific Health Board via an online system and approval for the study was obtained. In addition, Kocaeli University Faculty of Medicine Non-Invasive Clinical Research Ethics Committee granted ethical approval for the study with the date and number of 2020/36.

Statistical Package for the Social Sciences (SPSS), version 20 was used for statistical analysis (IBM Inc., Armonk, NY, USA). Results were prepared as frequency and percentages. Comparisons of categorical variables between groups were made using Pearson, Fisher's Full Chi-square test, Yates's Chi-square test and Monte Carlo Chi-square test. The ratios of categorical variables of the data between both periods were compared with Pearson, Fisher, Yates and Monte Carlo Chi Square tests.

\section{RESULTS}

A total of 93 respondents completed both parts of the survey. Demographic characteristics of the respondents are shown in Table 1. The academic level of most surgeons was Professor (48.4\%) and $85 \%$ of respondents had more than 10 years' experience undertaking breast surgery. Prior to the pandemic, two thirds of the respondents carried out between one and five operations per week, with the remainder performing more. In addition, more than half saw more than twenty patients per week as outpatients.

Workplace characteristics and the estimated effect of COVID-19 on service provision at each institution are shown in Table 2. More than three quarters of the respondents worked in university teaching hospitals with a further tenth working in private hospitals. The remainder were mostly divided between state hospitals and private practice. Most respondents were in the Marmara region, which includes Istanbul, by far the most populous city in Turkey, while very few were from the East and Southeast of the country. The variation in estimated effect of the COVID-19 pandemic was striking. Nearly 10\% stated that there were no cases whilst 30\% indicated that all available resources were directed to caring for the SARS-CoV-2 cases. A further 38\% reported that

\begin{tabular}{|l|c|}
\hline \multicolumn{2}{|l|}{ Table 1. Demographic information of the respondents } \\
\hline Demographics & $\mathbf{n}(\%)$ \\
\hline Academic level & $21(22.5)$ \\
$\quad$ Surgeon & $6(6.5)$ \\
Assistant Professor & $21(22.6)$ \\
Associated Professor & $45(48.4)$ \\
$\quad$ Professor & \\
\hline Specialization time & $14(15.1)$ \\
0-10 years & $29(31.2)$ \\
10-20 years & $37(39.8)$ \\
20-30 years & $13(14.0)$ \\
Over 30 years & \\
\hline Number of breast cancer surgeries before pande- & \\
mic (weekly) & $63(67.7)$ \\
1-5 & $24(25.8)$ \\
6-10 & $5(5.4)$ \\
More than 10 & $1(1.1)$ \\
None & \\
\hline Number of patients seen in outpatient breast can- & \\
cer clinics before pandemic (weekly) & $20(21.5)$ \\
1-10 & $21(22.6)$ \\
11-20 & $52(55.9)$ \\
More than 20 & $0(0)$ \\
\hline
\end{tabular}




\begin{tabular}{|c|c|}
\hline Information of Institutions & n (\%) \\
\hline \multicolumn{2}{|l|}{ Types of institutions } \\
\hline State hospital & $5(5.4)$ \\
\hline University (Training) hospital & $73(78.6)$ \\
\hline Private practice & $5(5.3)$ \\
\hline Private hospital & $9(9.6)$ \\
\hline Other & $1(1.1)$ \\
\hline \multicolumn{2}{|l|}{ Area where the institution is located } \\
\hline Marmara & $44(47.3)$ \\
\hline Aegean & $11(11.8)$ \\
\hline Black Sea & $5(5.4)$ \\
\hline Mediterranean & $7(7.5)$ \\
\hline Central Anatolia & $19(20.4)$ \\
\hline Eastern Anatolia & $3(3.2)$ \\
\hline Southeast Anatolia & $4(4.3)$ \\
\hline \multicolumn{2}{|l|}{$\begin{array}{l}\text { Impact of COVID-19 of the institution you are wor- } \\
\text { king with }\end{array}$} \\
\hline Unaffected: No COVID-19 patients & $7(7.5)$ \\
\hline $\begin{array}{l}\text { Slightly affected: Few COVID-19 patients are presen- } \\
\text { ting, resources (Ventilator, Personal protective equ- } \\
\text { ipment) and intensive care beds available }\end{array}$ & $35(37.6)$ \\
\hline $\begin{array}{l}\text { Moderately affected: Many COVID-19 patients pre- } \\
\text { senting, resources (Ventilator, personal protective } \\
\text { equipment) and intensive care beds limited }\end{array}$ & $25(26.9)$ \\
\hline $\begin{array}{l}\text { Very affected: Crisis situation in which all resources } \\
\text { and intensive care beds are directed to COVID-19 } \\
\text { patients }\end{array}$ & $26(28.0)$ \\
\hline \multicolumn{2}{|l|}{$\begin{array}{l}\text { Having a separate operating room for COVID-19 } \\
\text { suspicious or positive patients }\end{array}$} \\
\hline No & $32(34.4)$ \\
\hline Yes & 61 (65.6) \\
\hline
\end{tabular}

cases were being seen but that there were available resources and bed space while $27 \%$ stated that intensive care beds were limited. Two thirds had access to a designated COVID-19 operating theatre.

Respondents'feelings about relative risk and the precautions they undertook are shown in Table 3, divided by period. In the earlier period, more than forty percent had no contact while only fifteen percent had contact with a known COVID-19 patient. In the later period, the no known contact proportion dropped slightly whilst the known contact proportion increased to more than a quarter. Only a fifth had a personal COVID-19 diagnostic test (serology or imaging) in the first period, which increased to a third in Period 2. At the same time, less than a fifth took prophylaxis in period 1 which only increased marginally to $24 \%$ in Period 2 and the proportion reporting taking precautions in theatre did not change between the two periods, being 28\% and 30\% in Periods 1 and
2 , respectively. The biggest concern in both periods was transmitting the virus to family members, reported by sixty percent in both periods, followed by becoming personally infected. In addition, respondents felt patients requiring that general anesthesia posed more risk and, among breast surgery methods, oncoplastic surgery was thought to be riskier in terms of contagion to the surgeon.

Changes in surgical policy are shown in Table 4 for the two periods studied. In both periods, elective (benign) cases were largely stopped during the pandemic, with only cancer and emergency cases being operated. Daily practice was not stopped completely, and breast cancer surgeries were performed. Around half of respondents carried out 1-5 breast conserving and 1-5 mastectomies per week in both periods. This proportion dropped to around $45 \%$ of respondents performing between 1-5 oncoplastic operations, while nearly a quarter opted to perform no oncoplastic surgery in either period. Around 60\% reported no change in surgical technique in either period but this may have been because in Period 1 and 2,71\% and 75\% reported that patients suspected of COVID-19 were not undergoing surgery, Pre-operative COVID-19 testing was not widely performed, with only 3\% in Period 1 having either a PCR/serological test, CT thorax or even asked about the presence of symptoms while some centers assumed that all operated patients were positive and acted accordingly. This level of testing only rose to 10\% in Period 2. In Period 1 and 2 just over $40 \%$ reported no postponements with a further $37 \%$ reporting between 1-5 postponed operations per week in Period 1 which reduced to $31 \%$ in Period 2. The most common reason in both periods for postponement was patient anxiety.

Finally, respondents were asked about aspects of outpatient clinics, non-surgical therapy and diagnostic testing in the two periods (Table 5). In both periods, breast cancer outpatient services were available in $83 \%$ of respondent's centers although the referral rate to OPD decreased by more than $90 \%$ in both periods, indeed, benign breast disease outpatient appointments were postponed, if possible, in Period 1 with only $5 \%$ reporting continuing as before while a small number sought to refer patients to another center. In Period 2, this pattern had changed significantly $(p=0.005)$ with a fifth now reporting continuing as before while somewhat fewer (77\%) were postponing if possible and a similar number sought referral. Most outpatient appointments continued face-to-face while around a quarter used online or telephone communication. Two thirds of outpatient appointments were not taken if patients were suspected of COVID-19, although a small proportion of patients with possible COVID-19 continued to be seen in both periods. For existing patients receiving chemotherapy/radiotherapy/hormonotherapy, there was no disruption, with only $1-2 \%$ reporting any disruption for these services in both periods. For adjuvant therapies, there was more disruption, although more than $60 \%$ of these services continued as before 
Table 3. Respondents' attitudes to perceived risk of COVID-19 and precautions taken during the two pandemic periods

\begin{tabular}{|c|c|c|c|}
\hline & $\begin{array}{c}\text { Period } 1 \\
\text { n (\%) }\end{array}$ & $\begin{array}{c}\text { Period } 2 \\
\text { n (\%) }\end{array}$ & $\mathbf{p}$ \\
\hline $\begin{array}{l}\text { Contact with suspicious or positive COVID-19 patient } \\
\text { No } \\
\text { Contact with suspicious patient } \\
\text { Contact with COVID-19 positive patient } \\
\text { Unknown }\end{array}$ & $\begin{array}{l}38(40.9) \\
21(22.6) \\
14(15.1) \\
20(21.5)\end{array}$ & $\begin{array}{l}34(36.6) \\
17(18.3) \\
24(25.8) \\
18(19.4)\end{array}$ & 0.337 \\
\hline $\begin{array}{l}\text { Had personal COVID-19 testing or imaging } \\
\text { No } \\
\text { Yes }\end{array}$ & $\begin{array}{l}73(78.5) \\
20(21.5)\end{array}$ & $\begin{array}{l}62(66.7) \\
31(33.3)\end{array}$ & 0.071 \\
\hline $\begin{array}{l}\text { Had prophylactic or therapeutic treatment for COVID-19 } \\
\text { No } \\
\text { Yes }\end{array}$ & $\begin{array}{l}78(83.9) \\
15(16.1)\end{array}$ & $\begin{array}{l}71(76.3) \\
22(23.7)\end{array}$ & 0.270 \\
\hline $\begin{array}{l}\text { Additional precautions while using surgical cautery or sealing } \\
\text { agents during pandemic } \\
\text { No } \\
\text { Yes }\end{array}$ & $\begin{array}{l}67(72.0) \\
26(28.0)\end{array}$ & $\begin{array}{l}65(69.9) \\
28(30.1)\end{array}$ & 0.747 \\
\hline $\begin{array}{l}\text { Surgeons' personal feelings } \\
\text { I'm worried about being infected with COVID-19 } \\
\text { I am concerned about passing COVID-19 infection to my relatives } \\
\text { I am not concerned about becoming infected with COVID-19 or } \\
\text { transmission to anyone else with the measures I have taken }\end{array}$ & $\begin{array}{l}22(23.7) \\
56(60.2) \\
15(16.1)\end{array}$ & $\begin{array}{l}18(19.4) \\
57(61.3) \\
18(19.4)\end{array}$ & 0.711 \\
\hline $\begin{array}{l}\text { The risk to the surgeon depending on the type of anesthesia tech- } \\
\text { nique in patients with COVID-19 } \\
\text { Local or regional anesthesia } \\
\text { General anesthesia }\end{array}$ & $\begin{array}{l}34(36.6) \\
59(63.4)\end{array}$ & $\begin{array}{l}30(32.3) \\
63(67.7)\end{array}$ & 0.537 \\
\hline $\begin{array}{l}\text { Personal evaluation of risk of COVID-19 transmission during bre- } \\
\text { ast surgery by method } \\
\text { Breast conserving surgery } \\
\text { Mastectomy } \\
\text { Oncoplastic surgery }\end{array}$ & $\begin{array}{c}3(3.2) \\
36(38.7) \\
54(58.1)\end{array}$ & $\begin{array}{c}3(3.2) \\
33(35.5) \\
57(61.3)\end{array}$ & 0.924 \\
\hline
\end{tabular}

the epidemic. Just under half of the patients newly diagnosed with breast cancer were offered postponement of treatment, and if accepted, the delay was more than three weeks in around $70 \%$. Multidisciplinary breast clinics only continued as normal in $5 \%$ of the centers in both periods while there was a shift to video-conferencing for these clinics in around a fifth of centers. Radiological imaging was performed in more than $85 \%$ of the centers with reports being available in one week in most. Similarly, biopsies were performed as normal in more than $80 \%$ of the centers and most reports were available within two weeks, with less than 10\% taking longer than two weeks to report in both periods.

\section{DISCUSSION}

The COVID-19 pandemic has swept the globe. The first registered case of COVID-19 was recorded relatively late in Turkey on March $10^{\text {th }}, 2020$, and the period of rapid change and response from this date until the end of April 2020 is the first Period in this study. From the $1^{\text {st }}$ of May until the end of May, with the reduction in the number of cases and transition to the normalization process, may be considered the period of more rational adjustment and we have designated this Period 2 in the current study. Due to the high rate of infectiousness and positivity and especially because of the high rates of mortality in the co-morbidly ill and the elderly, the Turkish Ministry of Health called for extraordinary caution. All hospitals were required to change their normal practice with some degree of suspension of routine services, including cancer services, occurring. Priority was to be given to emergency cases, including in cancer services. Much disruption occurred to outpatient and surgery provision to protect the patients and those caring for them (6). Certain rules have been introduced for services providing emergency surgery to protect against COVID-19 (4). Due to this situation, there have been disruptions in some branches and slowdowns 
Table 4. Changes in breast cancer surgery practice during the two pandemic periods

\begin{tabular}{|c|c|c|c|}
\hline & $\begin{array}{l}\text { Period } 1 \\
\text { n (\%) }\end{array}$ & $\begin{array}{l}\text { Period } 2 \\
\text { n (\%) }\end{array}$ & $\mathbf{p}$ \\
\hline \multicolumn{4}{|l|}{ Change in daily surgery practice during pandemic } \\
\hline Daily practice unchanged compared to before pandemic & $5(5.4)$ & $6(6.5)$ & 0.219 \\
\hline Elective (benign) cases were stopped, only cancer and emergency & $62(66.7)$ & $71(76.3)$ & \\
\hline cases were operated & & & \\
\hline Elective (benign) and cancer cases were stopped, only emergency & $13(14.0)$ & $11(11.8)$ & \\
\hline cases were operated & & & \\
\hline Daily practice completely stopped & $13(14.0)$ & $5(5.4)$ & \\
\hline \multicolumn{4}{|l|}{ If the daily practice was stopped, what was the reason } \\
\hline Daily practice not stopped & $40(43.0)$ & $45(48.4)$ & 0.916 \\
\hline Surgeon on administrative leave due to age or comorbidity & $1(1.1)$ & $1(1.1)$ & \\
\hline Surgeon on administrative leave due to flexible work schedule & $16(17.3)$ & $15(16.1)$ & \\
\hline Personal protective equipment unavailable & $0(0)$ & $0(0)$ & \\
\hline Surgeon not performing surgery due to concerns about COVID-19 & $14(15.0)$ & $9(9.7)$ & \\
\hline Working at COVID-19 outpatient/service/intensive care surgery & $8(8.6)$ & $9(9.7)$ & \\
\hline Other & $14(15.1)$ & $14(15.1)$ & \\
\hline \multicolumn{4}{|l|}{ Breast cancer surgery performed } \\
\hline No & $23(24.7)$ & $13(14.0)$ & 0.095 \\
\hline Yes & $70(75.3)$ & $80(86.0)$ & \\
\hline \multicolumn{4}{|l|}{ Number of breast conserving surgeries performed } \\
\hline None & $6(6.5)$ & $5(5.4)$ & 0.815 \\
\hline $1-5$ & $45(48.4)$ & $49(52.7)$ & \\
\hline $6-10$ & $11(11.8)$ & $17(18.3)$ & \\
\hline More than 10 & $8(8.6)$ & $9(9.7)$ & \\
\hline \multicolumn{4}{|l|}{ Number of mastectomies performed } \\
\hline None & $12(12.9)$ & $14(15.1)$ & 0.850 \\
\hline $1-5$ & $47(50.5)$ & $49(52.7)$ & \\
\hline $6-10$ & $8(8.6)$ & $13(14.0)$ & \\
\hline More than 10 & $3(3.2)$ & $4(4.3)$ & \\
\hline \multicolumn{4}{|l|}{ Number of oncoplastic surgeries performed } \\
\hline None & $22(23.7)$ & $23(24.7)$ & 0.507 \\
\hline $1-5$ & $41(44.1)$ & $42(45.2)$ & \\
\hline $6-10$ & $5(5.4)$ & $10(10.8)$ & \\
\hline More than 10 & $2(2.2)$ & $5(5.4)$ & \\
\hline \multicolumn{4}{|l|}{ Surgical technical change due to pandemic } \\
\hline No & $53(57.0)$ & $58(62.4)$ & 0.794 \\
\hline Yes & $17(18.3)$ & $22(23.7)$ & \\
\hline \multicolumn{4}{|l|}{ COVID-19 suspected patients undergoing breast cancer surgery } \\
\hline No & 66 (71.0) & $70(75.3)$ & 0.253 \\
\hline Yes & $4(4.3)$ & $10(10.8)$ & \\
\hline \multicolumn{4}{|l|}{$\begin{array}{l}\text { Number of COVID-19 suspected patients undergoing breast can- } \\
\text { cer surgery }\end{array}$} \\
\hline $1-5$ & $4(4.3)$ & $9(9.7)$ & 1.000 \\
\hline $6-10$ & $0(0)$ & $1(1.1)$ & \\
\hline More than 10 & $0(0)$ & $0(0)$ & \\
\hline
\end{tabular}


Table 4. Changes in breast cancer surgery practice during the two pandemic periods (continue)

\begin{tabular}{|c|c|c|c|}
\hline & $\begin{array}{l}\text { Period } 1 \\
\text { n (\%) }\end{array}$ & $\begin{array}{l}\text { Period } 2 \\
\text { n (\%) }\end{array}$ & $\mathbf{p}$ \\
\hline \multicolumn{4}{|l|}{ Preoperative patient evaluation for COVID-19 } \\
\hline $\begin{array}{l}\text { All routinely tested (PCR/Fast antibody); result available prior to ope- } \\
\text { ration }\end{array}$ & $0(0)$ & $3(3.2)$ & 0.853 \\
\hline All had thoracic tomography; result available prior to operation & $1(1.1)$ & $3(3.2)$ & \\
\hline $\begin{array}{l}\text { Patients were asked about presence of symptoms (fever, cough, } \\
\text { dyspnea) only }\end{array}$ & $1(1.1)$ & $2(2.2)$ & \\
\hline $\begin{array}{l}\text { Additional evaluation was not subject to the only symptomatic in the } \\
\text { process was intervened }\end{array}$ & $0(0)$ & $0(0)$ & \\
\hline All patients assumed positive and appropriate precautions taken & $2(2.2)$ & $2(2.2)$ & \\
\hline \multicolumn{4}{|l|}{ Was a separate COVID-19 patient consent obtained prior to surgery? } \\
\hline No & $1(1.1)$ & $2(2.2)$ & 1.000 \\
\hline Yes & $3(3.2)$ & $8(8.6)$ & \\
\hline \multicolumn{4}{|l|}{ If no breast cancer surgery performed, what was the number of bre- } \\
\hline None & $41(44.1)$ & $43(46.2)$ & \\
\hline $1-5$ & $34(36.6)$ & $29(31.2)$ & \\
\hline $6-10$ & $12(12.9)$ & $13(14.0)$ & \\
\hline More than 10 & $6(6.5)$ & $8(8.6)$ & \\
\hline \multicolumn{4}{|l|}{ Causes of deferral for breast cancer surgeries if forced to postpone } \\
\hline Patient's anxiety or displacement & $39(42.1)$ & $43(46.5)$ & 0.954 \\
\hline Physician's anxiety or displacement & $5(5.4)$ & $4(4.3)$ & \\
\hline The institution does not allow & $16(17.3)$ & $16(17.3)$ & \\
\hline Physician's decision according to breast cancer subtypes & $20(21.5)$ & $18(19.4)$ & \\
\hline $\begin{array}{l}\text { Lack of information on what safe surgery will be like in COVID-19 Pan- } \\
\text { demic }\end{array}$ & $9(9.7)$ & $10(10.8)$ & \\
\hline $\begin{array}{l}\text { Lack of adequate equipment for hospital anesthesia or postoperative } \\
\text { care }\end{array}$ & $4(4.3)$ & $2(2.2)$ & \\
\hline
\end{tabular}

in health services. Although measures are taken and certain recommendations are made to prevent patients from being victims, it is thought that the biggest suffering is in cancer cases (5).

The disruption caused by the COVID-19 pandemic has also affected breast cancer patients and the services treating them (6). The aim of this survey was to assess the situation affecting breast cancer surgery and ancillary services in Turkey. Members of the Turkish Senology Academy (SENATURK) were approached for the disruption they had experienced and their opinions on the effects on services. Ninety-three breast surgeons from across the country responded to the online questionnaire. The responses were not homogeneous, and most respondents were working in university hospitals in the Marmara region of Northwest Turkey, with relatively low rates of population infection with COVID-19.

In this group with high surgical experience, it has been observed that there is generally no contact with COVID-19 posi- tive patients, surgeons do not need COVID-19 tests or imaging, and they do not use COVID-19 treatment for prophylactic or therapeutic purposes. When these two periods are evaluated, these data do not change. It has been revealed that surgical masks are used in the forefront in practice outside the operating room, while protective glasses, barrier, surgical mask and N95 masks are preferred more frequently in practice in the operating room. It has been observed that these measures taken are in line with those recommended in the literature (5). Again, in this group, additional measures were not taken for cautery or sealing devices. There was no difference between the two periods. It has been revealed that most of these surgeons work with anxiety to bring the COVID-19 infection to their relatives. This concern did not change in Period 2, when more information about COVID-19 was acquired, prevention measures increased, and the number of diseases decreased. The idea that surgeries performed under general anesthesia are riskier in terms of COVID-19 than local or regional anesthesia, and especially among breast surgery types, surgeries with oncoplastic breast 
Table 5. The availability of breast cancer outpatient and diagnostic services

\begin{tabular}{|c|c|c|c|}
\hline & $\begin{array}{l}\text { Period } 1 \\
\text { n (\%) }\end{array}$ & $\begin{array}{l}\text { Period } 2 \\
\mathrm{n}(\%)\end{array}$ & $\mathrm{p}$ \\
\hline \multicolumn{4}{|c|}{$\begin{array}{l}\text { Has the rate of referral to breast cancer outpatients been deliberately } \\
\text { decreased }\end{array}$} \\
\hline No & $6(6.5)$ & $8(8.6)$ & 0.782 \\
\hline Yes & $87(93.5)$ & $85(91.4)$ & \\
\hline \multicolumn{4}{|l|}{ Breast cancer outpatient clinic service available? } \\
\hline No & $16(17.2)$ & $16(17.2)$ & 1.000 \\
\hline Yes & $77(82.8)$ & $77(82.8)$ & \\
\hline \multicolumn{4}{|c|}{ Approach to benign breast diseases during pandemic } \\
\hline No change from pre-pandemic period & $5(5.4)$ & $19(20.4)$ & 0.005 \\
\hline Patients have been postponed, if possible & $85(91.4)$ & $72(77.4)$ & \\
\hline Routed to different center & $3(3.2)$ & $2(2.2)$ & \\
\hline \multicolumn{4}{|c|}{ Number of outpatients for breast cancer seen per week } \\
\hline None & $1(1.1)$ & $0(0)$ & 0.123 \\
\hline $1-5$ & $31(33.3)$ & $22(23.7)$ & \\
\hline $6-10$ & $24(25.8)$ & $22(23.7)$ & \\
\hline More than 10 & $21(22.6)$ & $33(35.5)$ & \\
\hline \multicolumn{4}{|l|}{ Breast cancer outpatient clinic contact type } \\
\hline Face-to-face & $54(58.1)$ & $52(55.9)$ & 0.824 \\
\hline Online & $14(15.1)$ & $17(18.4)$ & \\
\hline Telephone & $9(9.7)$ & $8(8,6)$ & \\
\hline \multicolumn{4}{|c|}{ Have you examined COVID-19 suspected patients in outpatient clinic } \\
\hline No & $66(71.0)$ & $62(66.7)$ & 0.495 \\
\hline Yes & $11(11.8)$ & $15(16.1)$ & \\
\hline \multicolumn{4}{|c|}{ Number of suspected patients with COVID-19 examined per week } \\
\hline $1-5$ & $9(9.7)$ & $15(16.1)$ & 0.169 \\
\hline $6-10$ & $2(2.2)$ & $0(0)$ & \\
\hline More than 10 & $0(0)$ & $0(0)$ & \\
\hline \multicolumn{4}{|c|}{$\begin{array}{l}\text { Number of breast cancer patients sent for non-surgical treatment during } \\
\text { this period }\end{array}$} \\
\hline None & $28(30.1)$ & $22(23.7)$ & 0.677 \\
\hline $1-5$ & $39(41.9)$ & $42(45.2)$ & \\
\hline $6-10$ & $21(22.6)$ & $21(22.6)$ & \\
\hline More than 10 & $5(5.4)$ & $8(8.6)$ & \\
\hline \multicolumn{4}{|c|}{ Examination request from patients operated before pandemic } \\
\hline None & $2(2.2)$ & $3(3.3)$ & 0.877 \\
\hline Yes & $79(85.0)$ & $77(82.8)$ & \\
\hline The patient came, but they weren't accepted & $2(2.2)$ & $1(1.1)$ & \\
\hline Internet or phone interview & $10(10.8)$ & $12(12.9)$ & \\
\hline \multicolumn{4}{|c|}{$\begin{array}{l}\text { Chemotherapy/radiotherapy/hormonotherapy adjustment status for } \\
\text { patients undergoing pre-pandemic surgery }\end{array}$} \\
\hline Not performed & $1(1.1)$ & $2(2.2)$ & 1.000 \\
\hline Performed & $92(98.9)$ & 91 (97.8) & \\
\hline
\end{tabular}


Table 5. The availability of breast cancer outpatient and diagnostic services (continue)

\begin{tabular}{|c|c|c|c|}
\hline & $\begin{array}{c}\text { Period } 1 \\
\text { n (\%) }\end{array}$ & $\begin{array}{c}\text { Period } 2 \\
\text { n (\%) }\end{array}$ & $p$ \\
\hline $\begin{array}{l}\text { Number of patients whose adjuvant treatment was disrupted } \\
\text { None } \\
1-5 \\
6-10 \\
\text { More than } 10\end{array}$ & $\begin{array}{c}56(60.2) \\
29(31.2) \\
5(5.4) \\
3(3.2)\end{array}$ & $\begin{array}{l}58(62.4) \\
22(23.7) \\
11(11.8) \\
2(2.2)\end{array}$ & 0.316 \\
\hline $\begin{array}{l}\text { Patient diagnosed with breast cancer but offered postponement } \\
\text { No } \\
\text { Yes }\end{array}$ & $\begin{array}{l}48(51.6) \\
45(48.4)\end{array}$ & $\begin{array}{l}51(54.8) \\
42(45.2)\end{array}$ & 0.769 \\
\hline $\begin{array}{l}\text { Postponement delay of patients diagnosed with breast cancer } \\
\text { 1-2 weeks } \\
\text { 3-4 weeks } \\
\text { More than } 4 \text { weeks }\end{array}$ & $\begin{array}{l}25(26.9) \\
37(39.8) \\
31(33.3)\end{array}$ & $\begin{array}{l}31(33.3) \\
32(34.4) \\
30(32.3)\end{array}$ & 0.600 \\
\hline $\begin{array}{l}\text { Multidisciplinary breast council meetings held? } \\
\text { No } \\
\text { Yes }\end{array}$ & $\begin{array}{l}65(69.9) \\
28(30.1)\end{array}$ & $\begin{array}{l}61(65.6) \\
32(34.4)\end{array}$ & 0.530 \\
\hline $\begin{array}{l}\text { If the multidisciplinary breast council held, how did it meet? } \\
\text { Scheduled but canceled } \\
\text { As usual } \\
\text { Reducing the number of participants } \\
\text { Video-conferencing or online }\end{array}$ & $\begin{array}{c}2(2.2) \\
5(5.4) \\
3(3.2) \\
18(19.4)\end{array}$ & $\begin{array}{c}1(1.1) \\
5(5.4) \\
5(5.4) \\
21(22.6)\end{array}$ & 0.863 \\
\hline $\begin{array}{l}\text { Radiological imaging during pandemic period } \\
\text { Not performed } \\
\text { Performed }\end{array}$ & $\begin{array}{l}14(15.1) \\
79(84.9)\end{array}$ & $\begin{array}{l}10(10.8) \\
82(89.2)\end{array}$ & 0.530 \\
\hline $\begin{array}{l}\text { Time to final report of radiological images } \\
\text { 1-7 days } \\
\text { 8-15 days } \\
\text { More than } 15 \text { days }\end{array}$ & $\begin{array}{c}67(72.0) \\
8(8.6) \\
4(4.3)\end{array}$ & $\begin{array}{c}64(68.8) \\
16(17.2) \\
3(3.2)\end{array}$ & 0.264 \\
\hline $\begin{array}{l}\text { Biopsy during pandemic period } \\
\text { Not performed } \\
\text { Performed }\end{array}$ & $\begin{array}{l}17(18.3) \\
76(81.7)\end{array}$ & $\begin{array}{l}12(12.9) \\
81(87.1)\end{array}$ & 0.419 \\
\hline $\begin{array}{l}\text { Reporting time of biopsy results } \\
\text { 1-7 days } \\
8-15 \text { days } \\
\text { More than } 15 \text { days }\end{array}$ & $\begin{array}{c}37(39.8) \\
31(33.3) \\
8(8.6)\end{array}$ & $\begin{array}{c}39(41.9) \\
35(37.6) \\
7(7.5)\end{array}$ & 0.904 \\
\hline
\end{tabular}

surgery techniques may have a higher risk in terms of COVID-19 transmission. Results were followed in parallel in both periods. Again, this information was found to be consistent in the light of the literature (3).

In line with the data obtained, the changes in breast cancer surgery preferences during this period were evaluated. In both periods, elective (benign) cases were stopped, only cancer and emergency cases were taken into surgery, and daily practice was not stopped. Contrary to what is thought, this shows that in the COVID-19 pandemic, it does not cause disruption in the surgical treatment of cancer patients. This situation was the same in terms of breast cancer surgeries, and breast cancer surgeries were not interrupted, especially in health institutions, the majority of which were university hospitals. It is seen from the data that such a disruption did not occur even in the $1^{\text {st }}$ Period when COVID-19 was most active.

As breast cancer surgery, breast conserving surgery, mastectomy and oncoplastic surgery preferences were at the same level on average in both periods, they did not have superiority to each other in preference, and surgical techniques were not changed due to pandemic. It wasobserved that especially in patients whose neoadjuvant treatment was completed, the op- 
erations that were the continuation of the treatment were performed primarily and there was no setback. Although the majority of patients who were operated on for breast cancer were COVID-19 negative, a small number of patients with COVID-19 positive breast cancer was operated and received special consent from these patients. An increase in the rate of COVID-19 positive patients was observed, especially in Period 2. In this Period 2, the increase in the measures taken against the disease and the decrease of fear shows the result that the priority of the treatment of cancer patients is important. Again, although the number of COVID-19 positive breast cancer surgeries is low, it is understood from the data that all patients were taken into surgery by taking precautions as if they were COVID-19 positive. Patients who needed breast cancer surgery were mostly not postponed, and a small number of patients were postponed due to the anxiety of the patient. This is similar in both periods.

In addition to evaluating the surgical status of breast cancer patients, the outpatient clinic and diagnostic situations during this period were also evaluated. Although there was a significant decrease in the rates of breast cancer referrals to outpatient clinics, there was no disruption in outpatient clinic services, but patients who applied for benign breast diseases were delayed as much as possible. When both periods were examined, this situation did not change, but benign breast patients were delayed less in Period 2. While in the 1st Period, an average of 5 breast cancer patients per week were given outpatient services per surgeon, this number increased, and the average exceeded 10 patients in Period 2. The majority of this was in the form of face-to-face examination and there was no difference in both periods. Most breast cancer outpatients have been found to be COVID-19 negative. At the end of the examination, no disruption was observed in both periods in terms of sending to surgical treatment.

Another important issue is the situation in neoadjuvant or adjuvant treatments of breast cancer patients during this period. In this regard, guidelines have been determined for the COVID-19 period and the continuity of treatment has been attempted (8, 9). It has been essential that patients with priority should receive their treatment in isolated environments. In our evaluation in our country, there was a significant demand by patients for the control examinations of patients who had pre-pandemic surgery, that the follow-up treatments such as chemotherapy/ radiotherapy/hormonotherapy could be adjusted without any problems, and adjuvant treatments were mostly not interrupted in both periods.

The rate of delaying the treatment of breast cancer in both periods was equal, the patients who were delayed were postponed for an average of 4 weeks, and the patients accepted this delay by expressing their concerns.

Another disruption in diagnostic services is that multidisciplinary breast councils are mostly not held in both periods. Vid- eo conference or online communication methods were preferred in the group. In both periods, the radiological imaging of breast cancer patients was mostly performed, there was no decrease in terms of imaging technique, and the results were obtained within an average of 7 days. Apart from the pandemic, there is no setback in this respect, considering that the report is issued in an average of 7 days in institutions. Again, it was seen that breast cancer patients could be biopsied for pathological diagnosis and reported within an average of 7 days, and since there was no difference in comparison with normal time, the COVID-19 pandemic did not cause disruption in the pathological diagnostic biopsies of breast cancer patients. These results were parallel for both periods.

As a result, as in the whole world except Turkey, it has also experienced serious interruptions of taking serious measures to fight pandemics tried COVID-19 due to urgent and priority health care services in cancer patients. According to our study, breast cancer patients did not experience interruptions in terms of outpatient clinic service, surgery service, postoperative adjuvant treatment and control services due to these pauses and disruptions. Except for less multidisciplinary breast councils, there was no delay in radiological and pathological diagnoses. Especially when considered as Period 1 between March 11, 2020, and April 30, 2020 and Period 2 between May 1, 2020 and May 31, 2020, the number of breast cancer surgeries increased in Period 2, and more COVID-19 positive breast cancer patients had been operated in the Period 2. Benign breast patients were delayed less frequently in the Period 2. In the statistical analysis performed between the two groups, it was found that only a significant difference was in the number of outpatients with benign breasts.

With sufficient awareness about the pandemic and with the measures of institutions, it is concluded breast cancer during the period of active pandemic in the terms of service to patients between March 11, 2020, through May 31, 2020 passed without a hitch in Turkey.

\section{Acknowledgments}

We thank to Jeremy Jones for revising the English language of the paper and thank to Canan Baydemir for her help with statistical analyses.

Ethics Committee Approval: This study was obtained from Kocaeli University Non-Invasive Clinical Research Ethics Committee (Date: 03.08.2020, No: 2020/236.

Peer-review: Externally peer-reviewed.

Author Contributions: Concept -S.A.G., T.Ş.; Design - N.Z.C.; Supervision -N.Z.C., Ö.Ö.G.; Materials - N.Z.C.; Data Collection and/or Processing - Ö.Ö.G., T.S.; Analysis and/or Interpretation - S.A.G., Ö.Ö.G.; Literature Search- S.A.G.; Writing Manuscript - S.A.G.; Critical Reviews - N.Z.C., Ö.Ö.G.

Conflict of Interest: The authors have no conflicts of interest to declare.

Financial Disclosure: The authors declared that this study has received no financial support. 


\section{REFERENCES}

1. Kakodkar P, Kaka N, Baig NM. A comprehensive literature review on the clinical presentation, and management of the pandemic Coronavirus Disease 2019 (COVID-19). Cureus 2020; 12: e7560. [CrossRef]

2. Al-Shamsi HO, Alhazzani W, Alhuraji A, Coomes EA, Chemaly RF, Almuhanna $M$, et al. A practical approach to the management of cancer patients during the novel Coronavirus Disease 2019 (COVID-19) pandemic: An International Collaborative Group. Oncologist 2020; 25: e936-e945. [CrossRef]

3. Dietz RJ, Moran MS, Isakoff SJ, Kurtzman SH, Willey SC, Burstein HJ, et al. Recommendations for prioritization, treatment, and triage of breast cancer patients during the COVID-19 pandemic. the COVID-19 pandemic breast cancer consortium. Breast Cancer Res Treat 2020; 181:487-97. [CrossRef]

4. Kamer E, Çolak T. What to do when a patient infected with COVID-19 needs an operation: A pre-surgery, peri-surgery and post-surgery guide. Turk J Colorectal Dis 2020; 30: 1-8. [CrossRef]
5. Finley C, Prashad A, Camuso N, Daly C, Aprikian A, Ball CG, et al. Guidance for management of cancer surgery during the COVID-19 pandemic. Can J Surg 2020; 63: S2-S4. [CrossRef]

6. Çakmak GK, Özmen V. Sars-CoV-2 (COVID-19) outbreak and breast cancer surgery in Turkey. Eur J Breast Health 2020; 16(2): 83-85. [CrossRef]

7. Soran A, Gimbel M, Diego E. Breast cancer diagnosis, treatment and follow-up during COVID-19 pandemic. Eur J Breast Health 2020; 16: 86-8. [CrossRef]

8. Coles CE, Aristei C, Bliss J, Boersma L, Brunt AM, Chatterjee S, et al. International guidelines on radiation therapy for breast cancer during the COVID-19 pandemic. Clin Oncol (R Coll Radiol) 2020; 32: 279-81. [CrossRef]

9. Braunstein LZ, Gillespie EF, Hong L, XU A, Bakhoum SF, Cuaron J, et al. Breast radiotherapy under COVID-19 pandemic resource constraintsapproaches to defer or shorten treatment from a Comprehensive Cancer Center in the United States. Adv Radiat Oncol 2020; 5: 582-8. [CrossRef]

\title{
ORIJINAL ÇALIŞMA-ÖZET
}

Turk J Surg 2021; 37 (3): 222-231

\section{Türkiye'de COVID-19 pandemisinin yaşandığı iki aktif dönemde, meme kanserinin tanı, tedavi ve takibinde yaşanan değişimler ve aksamalar}

\author{
Sertaç Ata Güler ${ }^{1}$, Özlem Özkan Güler ${ }^{2}$, Turgay Şimşek ${ }^{1}$, Nuh Zafer Cantürk \\ 1 Kocaeli Üniversitesi Tıp Fakültesi, Genel Cerrahi Anabilim Dalı, Kocaeli, Türkiye \\ ${ }^{2}$ Kocaeli Üniversitesi Tıp Fakültesi, Enfeksiyon Hastalıkları ve Klinik Mikrobiyoloji Anabilim Dalı, Kocaeli, Türkiye
}

\section{ÖZET}

Giriş ve Amaç: Tüm dünyada hızla yayılarak kısa sürede pandemi haline gelen COVID-19 hastalığı sebebiyle her alanda olduğu gibi, özellikle sağlık alanında da rutinler bozularak, verilen sağlık hizmetlerinde önemli değişiklikler yapılamasına karar verilmiştir. Bu süreçte özellikle mevcut sağlık kurumlarında verilen rutin sağlık hizmetlerinde COVID-19 ile savaş sebebiyle belirli kısıtlamalara gidilmiştir. Yapılacak cerrahilerin öncesi, esnası ve sonrası için uyulması önerilen kurallar ortaya koyulmuştur. Meme kanseri tanı, tedavi ve takibi için verilen sağlık hizmetleri de bu sebeple belli değişimlere uğramıştır. Önceliği olan hastaların tanı, tedavi ve takibi gündeme gelmiştir. Bu çalışmada Türkiye'de COVID-19'un aktif olarak yaşandığı 11 Mart 2020 ile 31 Mayıs 2020 arasındaki süreç, 2 döneme ayrılarak, meme kanseri tanı, tedavi ve takibi, hizmet veren cerrahların ve kurumların etkilenme süreci ile birlikte değerlendirilmiştir.

Gereç ve Yöntem: SENATURK (Türkiye Senoloji Akademisi)'ne kayıtlı, Türkiye'de meme kanseri tedavisi ile uğraşan cerrahlara çevrimiçi yollarla ulaşılarak elektronik olarak hazırlanan değerlendirme formu iletilmiş ve alınan cevaplar değerlendirilmiştir.

Bulgular: 93 katılımcının verileri değerlendirilmiştir. Multidisipliner meme konseylerinin daha az yapılması dışında, radyolojik ve patolojik tanılarda gecikme olmamıştır. 2. dönemde meme kanseri ameliyatı sayısı artmıştır ve ameliyat edilen COVID-19 pozitif meme kanseri hasta sayısı artmıştır. 2. dönemde benign meme hastalıkları açısından daha az gecikme kaydedilmiştir. Her iki grupta ayakta tedavi gören benign meme hastalarının sayısında sadece anlamlı farkın olduğu bulunmuştur.

Sonuç: Cerrahların COVID-19 pandemisi hakkında yeterli bilinçte olması hem kurumsal hem de kişisel önlemler alınmasıyla meme kanseri hastalarına hizmet açısından COVID-19 pandemisinin 11 Mart 2020 ile 31 Mayıs 2020 arasındaki aktif pandemi döneminde Türkiye'de genel olarak aksama olmadan hizmet verilmeye çalışıldığı sonucuna varılmışır.

Anahtar Kelimeler: Meme kanseri, COVID-19, meme sağlığı, meme cerrahisi, aksama

Doi: $10.47717 /$ turkjsurg.2021.5069 